\title{
Synthesis and Assignments of Regioisomeric Cyanoimidazole Esters
}

\author{
Ramachandran P. Subrayan, ${ }^{\dagger}$ Ernest L. Thurber ${ }^{\ddagger}$ and Paul G. Rasmussen* \\ Department of Chemistry ${ }^{\dagger}$ and Macromolecular Science and Engineering ${ }^{\ddagger}$ \\ The University of Michigan, Ann Atbor, MI 48109
}

\begin{abstract}
Regioassignments of ethyl cyanoimidazolecarboxylates have been performed by the nuclear Overhauser effect(NOE) studies on the regioisomeric monocyanoimidazoles obtained by the hydrolysis of the esters followed by decarboxylation. Allemately, reginassignment could also be carried out by comparing the chemical shifts of the $\mathbf{N}$-methyl groups.
\end{abstract}

\section{INTRODUCTION}

The chemistry of imidazoles has been of considerable biological significance. Our group has been particularly interested in the chemistry of cyanoimidazoles. ${ }^{1}$ Cyanoimidazoles can be used in herbicides ${ }^{2}$, fungicides, ${ }^{3}$ and dyes. ${ }^{4}$ They are also used in the synthesis of copolymers, ${ }^{5}$ as ligands to metals in anisotropic conductors ${ }^{6}$ and as electron acceptors in charge-transfer solids. ${ }^{1 d}$ They are also of interest as monomers with the aim of synthesizing high nitrogen and low hydrogen content polymers that are likely to be thermally stable and have low flammability. We have synthesized several polyamides starting from cyanoimidazole based amino acids. ${ }^{7}$ An important aspect of using imidazoles is the assignment of their regiochemistry. Here we report results on the regioassignment of esters derived from cyanoimidazoles.

Assignments of regiochemistry have been reported for the imidazole moiety in histidine derivatives. Earlier work defined the regioisomeric imidazoles by crystallography and chemical degradation. ${ }^{8}$ Regioassignments in imidazoles have also been made by unambiguous synthesis of the desired imidazole systems. ${ }^{9}$ Matthews and Rapoport have proposed empirical rules based on observed cross coupling constants between imidazole protons. ${ }^{10}$ These rules have been adopted by others in assigning the regiochemistry of the imidazoles. ${ }^{11}$ However, these empirical rules are not applicable to completely substituted imidazoles.

Yasuda et al. 12 have reported the use of the chemical shift of the 1-methyl group as a guide for assignment of regioisomeric 4(5)-amido-1-methylimidazole-5(4)imidazole esters, based on the preliminary work by Showalter et al. ${ }^{13}$ The chemical shifts of the $\mathrm{N}$-methyl groups of the regioisomeric imidazoles (1 and 2) are shown below. This approach seems to be applicable when both 4 and 5 positions are substituted. The methyl group adjacent to the amide group in 1 shows a downfield chemical shift. The amide carbonyl of 1 is nearer to the $\mathrm{N}$-methyl group, due to an unusual intramolecular hydrogen bonding of the amide hydrogen with the ester carbonyl group, and induces a downfield shift to the signal from the $\mathrm{N}$-methyl hydrogens. ${ }^{5 b-c}$ 


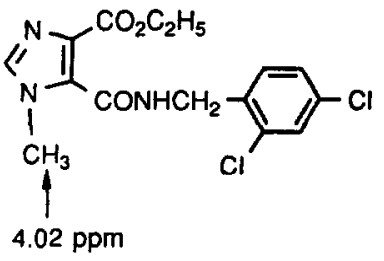

1

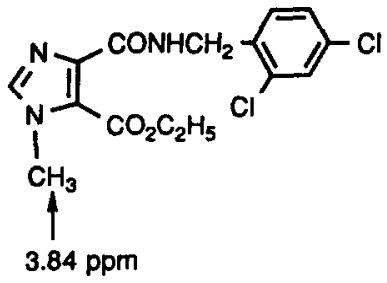

2
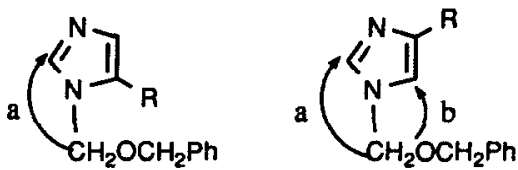

3

4

A more reliable technique uses the nuclear Overhauser effect (NOE). NOEs have been reported by Graden et al. ${ }^{14}$ to verify the position of $\mathrm{N}$-benzyloxymethyl protecting group on the D-histidine residue of histrelin ( 3 and 4 ) as shown above. In 3, NOE was observed between the H-2 imidazole proton and the methylene protons of the benzyloxymethyl group while in 4 , NOE was observed between the $\mathbf{H}-\mathbf{2}$ and $\mathrm{H}-4$ protons and the methylene protons of the benzyloxymethyl group. Jones et al. also reported similar NOE studies on various histidine derivatives substituted with different protecting groups. ${ }^{15}$ Markley et al. have used one- and two-dimensional NOE experiments for the assignment of the imidazolium $\mathrm{N}^{-1} \mathrm{H}$ peaks in the ${ }^{1} \mathrm{H}$ NMR of histidine residues in proteins. ${ }^{16}$

Recently, Banoub et al. reported the use of fast atom bombardment (FAB) mass spectrometry in the structural characterization of anomeric and regioisomeric ethyl 5(4)-amino-2'-deoxy-D-erythropentofuranosylimidazole-4(5)-carboxylate nucleosides. ${ }^{17}$ The fragmentations observed were explained based on the chemical free energy and the stereochemical differences of the substituents located on the C-4 and C-5 of the imidazole, and also of the anomeric configurations of C-1' of the 2-deoxyribose position.

Generally, substitution at the 1-position of the imidazole is also influenced by the steric hindrance of the substituent at the 5-carbon. For example, $\mathrm{N}$-alkylation of 2-bromo-4(5)-methyl-5(4)-imidazolecarboxylate using bulkier groups such as isopropyl and phenylsulfinylmethyl give predominantly the isomer where the substituent is away from the carboxylate moiety. ${ }^{18}$ However, this is not true for smaller alkylating groups.

The mass spectrometric data obtained for the regioisomeric cyanoimidazole based amino acids or their esters, appeared to be more or less similar in their fragmentation pattems. Therefore definitive information could not be discerned from the mass spectrometric data regarding their regiochemistry. Instead, the differences in the chemical shifts of the $\mathrm{N}$-methyl groups and also the NOE studies were helpful in the regioassignments.

In order to perform NOE studies, we synthesized monocyanoimidazole derivatives according to the following scheme: dicyanoimidazoles were subjected to monoethanolysis to give the corresponding ethyl esters. The esters were methylated at the 1-position to give regioisomers which were separated by column chromatography or by fractional crystallization. These esters were hydrolyzed to the acids and finally, the acids were subjected to thermal decarboxylation to give the monocyanoimidazoles.

The concept of selective decarboxylation in imidazoles is not new. Nematollahi et al. reported the syntheses of derivatives of 4(5)-imidazolecarboxylic acid from 4,5-imidazoledicarboxylic acid. ${ }^{19}$ Takahashi et al. reported selective decarboxylation of 4,5-dicyano-1-methylimidazole dicarboxylic acid by pyrolysis and in solution upon reflux. ${ }^{20}$ We were able to subject 2-amino-1-methyl-4,5-imidazoledicarboxylic acid to monodecarboxylation to give rise to 2-amino-1-methyl-5-imidazolecarboxylic acid. ${ }^{\text {a, }, 21}$ Rappoport et al. used 
this method for the unambiguous synthesis of imidazole quinoxalines. 22 Kim et al. used decarboxylation of salts of imidazole-4(5)-carboxylic acids to synthesize the corresponding hydroxymethylimidazoles. ${ }^{23}$

\section{RESULTS AND DISCUSSION}

\section{Monoethanolysis of Dicyanoimidazoles}

Monoethanolysis of 4,5-dicyanoimidazole(5), 2-amino-4,5-dicyanoimidazole(6) and 2-bromo-4,5dicyanoimidazole(7) was accomplished using a modified Pinner synthesis. 24 Thus, when compounds 5, 6 and 7 were allowed to react with excess ethanol(95\%) in the presence of 1-2 equivalents of sulfuric acid, the corresponding ethyl esters $5 a, 6 a$ and 7a were obtained (Scheme 1).25

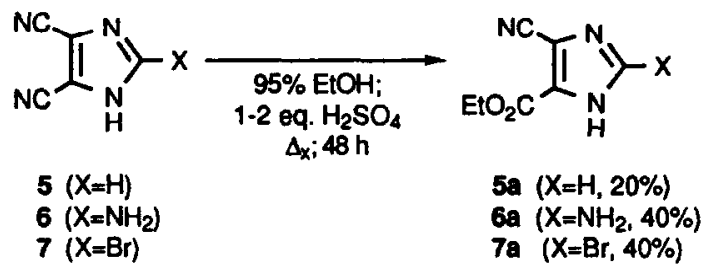

Scheme 1

High yields are generally not obtained since the reaction involves several reversible steps but the starting materials could be recovered and recycled.

\section{N-methylation of Ethyl Cyanoimidazolecarboxylates}

The products obtained from the monoethanolysis, 5a, 6a and 7a, were methylated at the 1-position using dimethyl sulfate, according to the reaction conditions in Scheme 2, resulting in regioisomeric mixtures.

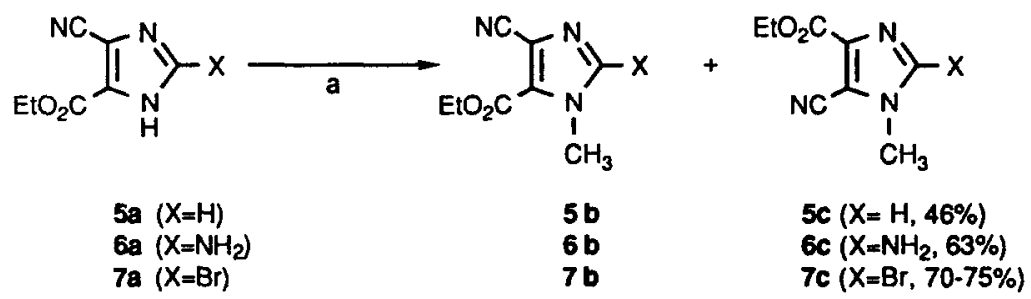

${ }^{a}$ For $\mathrm{X}=\mathrm{H}$ or $\mathrm{NH}_{2}:$ 1. $\mathrm{NaH}, \mathrm{DMF}, 0^{\circ} \mathrm{C} ; 2 . \mathrm{Me}_{2} \mathrm{SO}_{4}, 0^{\circ} \mathrm{C}$ - r.t.

For $X=B r: 1 . \mathrm{NaHCO}_{3} \cdot \mathrm{H}_{2} \mathrm{O} .60^{\circ} \mathrm{C} ; 2 . \mathrm{Me}_{2} \mathrm{SO}_{4}$ or 1. Et ${ }_{3} \mathrm{~N}$. THF, r.t. 2. $\mathrm{Me}_{2} \mathrm{SO}_{4}$

\section{Scheme 2}

Among the regioisomers, those derivatives where the ester group is at the 5-position are tentatively assigned $5 b, 6 b$ and $7 b$ while those of the 4-esters are tentatively assigned $5 c, 6 c$ and $7 c$. The regioisomeric compositions of the $\mathrm{N}$-methylated cyanoimidazole esters(5b-c, $6 \mathrm{~b}-\mathrm{c}$ and $7 \mathrm{~b}$-c) were determined by gas chromatography or by ${ }^{1} \mathrm{H}$ NMR spectroscopy and the results are listed in Table 1. 
Table 1. Regioisomeric Ratios of Cyanoimidazole Esters

\begin{tabular}{|c|c|c|}
\hline $\begin{array}{c}\text { Starting } \\
\text { material }\end{array}$ & Products & Isomer ratio \\
\hline $\mathbf{5 a}$ & $\mathbf{5 b} \& \mathbf{5 c}$ & $3: 1$ \\
\hline $\mathbf{6 a}$ & $\mathbf{6 b} \& \mathbf{6 c}$ & $2: 1$ \\
\hline $\mathbf{7 a}$ & $\mathbf{7 b} \& \mathbf{c} \mathbf{c}$ & $3: 1$ \\
\hline
\end{tabular}

If the methylation is carried out in large scale, the ratio of the 5-ester to 4-ester increases considerably. ${ }^{26}$ Apparently the ester carbonyl group assists in the transmethylation to give predominantly the 5-ester. The regioisomers $5 \mathrm{~b}$ and $\mathbf{5 c}$ were separated by column chromatography using ethyl acetate as eluent. Regioisomers 6b and $6 c$ were separated by fractional crystallization, first from water to give $\mathbf{6 b}$ and secondly from isopropanol to give $6 c$. Among the regioisomers $7 b$ and $7 c$, one of them could be separated by crystallization from water and acetone as the first crop. Attempts to separate the second regioisomer by fractional crystallization from hexane/methylene chloride or petroleum ether/carbon tetrachloride mixture were not successful. Usually the first crop of crystals appear to be long, thin and silky white which look like glass wool ! Perhaps, the molecules stack along the long axis of the crystal.27 Column chromatography was employed to separate $7 \mathrm{~b}$ and $7 \mathrm{c}$ using methylene chloride as the eluent but no separation of the regioisomers was noticed.

\section{Hydrolysis of Ethyl $\mathrm{N}$-methyl-cyanoimidazolecarboxylates}

As a prelude to decarboxylation, hydrolysis of the regioisomeric esters were performed using 1.0 equivalent tetraethylammonium hydroxide in aqueous medium. Higher temperatures on the order of $70-80^{\circ} \mathrm{C}$ were needed for the 2-amino substituted esters while the hydrolysis took place readily at room temperature for other esters. A typical reaction is shown in Scheme 3.<smiles>CCOc1c(C#N)nc(C)n1C</smiles>

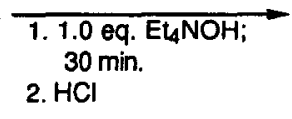

\section{Scheme 3}<smiles>[X]c1nc(C#N)c(CO)n1C</smiles>

$\left(\mathrm{X}=\mathrm{H}, \mathrm{NH}_{2}, \mathrm{Br}\right)$

\section{Decarboxylation of $\mathbf{N}$-methyl-cyanoimidazolecarboxylic Acids}

The cyanoimidazole based carboxylic acids, obtained from the esters by the base catalyzed hydrolysis, undergo decarboxylation upon heating. Thermal decarboxylation was performed by heating these acids in a test tube on a sand bath preheated to their decomposition temperatures. A typical reaction is shown in Scheme 4. 


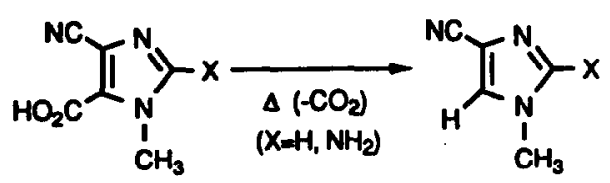

\section{Scheme 4}

Not all acids underwent thermal decarboxylation. For example, 5-cyano-1-methyl-4-imidazolecarboxylic acid (5e) sublimed under the reaction conditions. The sublimation of Se may be attributed to the strong intramolecular hydrogen bonding of the carboxylic hydrogen with the 3-nitrogen or due to intermolecular hydrogen bonding between carboxylic acid groups. 2-Bromo substituted derivatives (7d and 7e), on the other hand, appeared to decompose with the elimination of bromine. The decomposition of $7 \mathbf{d}$ was examined using thermogravimetry and the results of the thermogravimetric analysis are shown in Figures 1 and 2. The acid, 7d, showed the onset of decomposition at about $200^{\circ} \mathrm{C}$ and there was a single weight loss of nearly $70 \mathrm{wt} \%$. When the same decomposition was carried out isothermally at $185^{\circ} \mathrm{C}$, below the onset of the decomposition temperature, an initial weight loss of approximately $35 \mathrm{wt} . \%$ was noticed which might account for the loss of bromine. Thus, no 2-bromocyanoimidazoles were obtainable for NOE studies.

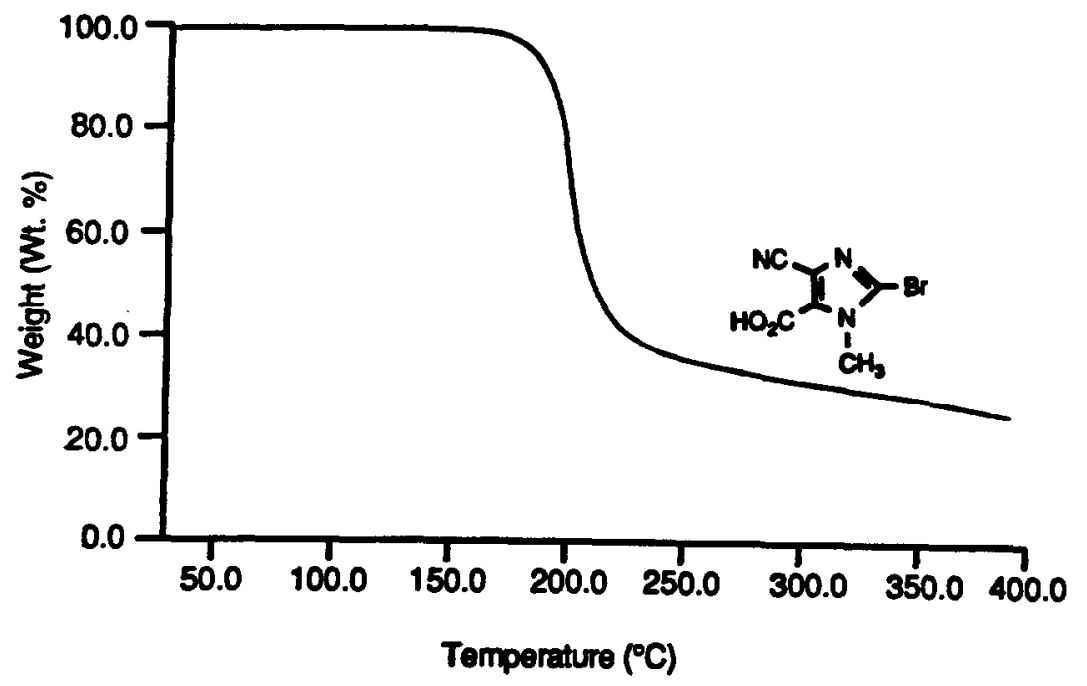

Figure 1. Thermogravimetric Analysis (TGA) of 2-Bromo-4-cyano-1-methyl-5-imidazolecarboxylic acid (7d); 


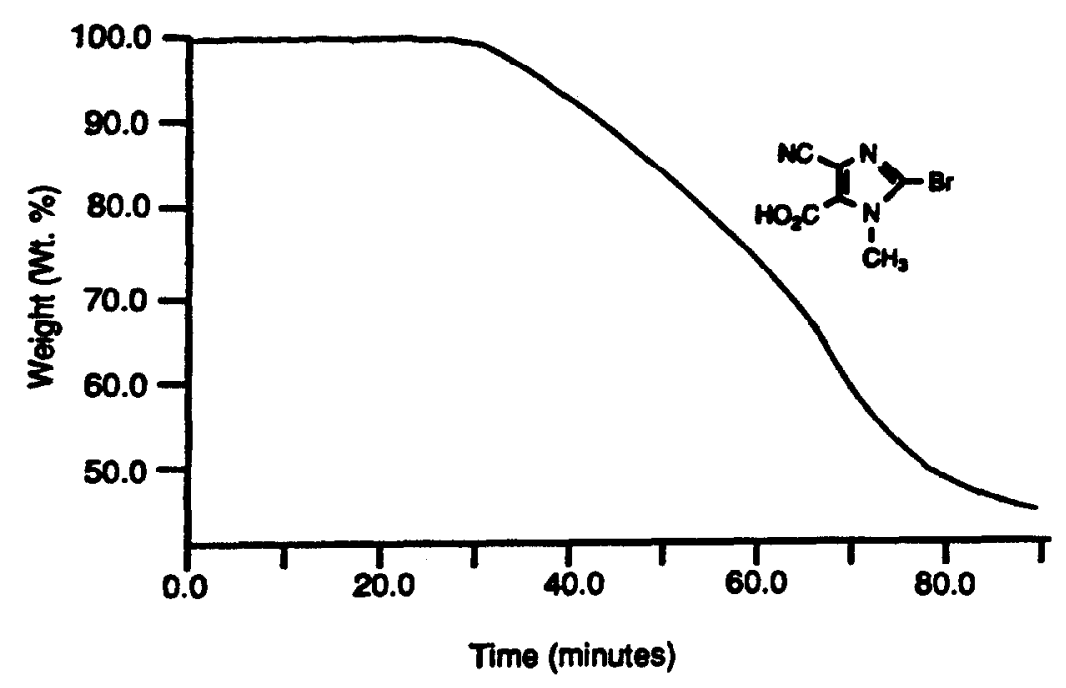

Figure 2. Isothermal Thermogravimetric Analysis (TGA) of 2-Bromo-4-cyano-1-methyl-5-imidazolecarboxylic acid (7d) at $185^{\circ} \mathrm{C}$ in air

\section{NOE Studies on N-methyl-cyanoimidazoles}

NOE studies were performed by irradiating the methyl hydrogens and observing any enhancements in the signals of the aromatic hydrogens. The observed difference NOE data is listed in Table 2.

Table 2. Observed Difference NOE Data

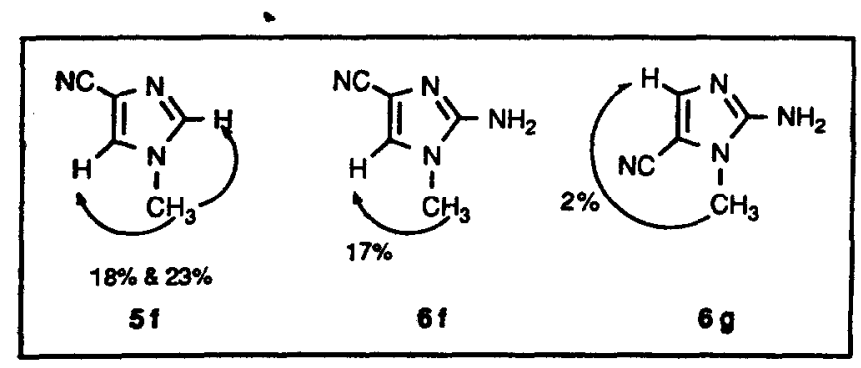

The results of the NOE experiments for $5 f$ and $6 f$ show that the hydrogen is at the 5-carbon. Compounds $5 f$ and $6 f$ were synthesized from the esters $5 b$ and $6 \mathrm{~b}$ respectively. Therefore the esters $5 b$ and $6 \mathrm{~b}$ must have the ester group at the 5-carbon. Consequently, their regioisomeric esters $5 \mathrm{c}$ and $6 \mathrm{c}$ must have the ester group at the 4-carbon.

To arrive at the regioassignment of the bromo esters, the chemical shifts of the $\mathrm{N}$-methyl groups were compared for all the regioisomeric compounds synthesized. The chemical shifts of the various cyanoimidazole derivatives are listed in Tables 3-5. 
Table 3. Chemical Shifts of $\mathrm{N}-\mathrm{CH}_{3}$ in Cyanoimidazole Derivatives

\begin{tabular}{|c|c|c|c|}
\hline Compound & $\delta$ (ppm) & Compound & $\delta(\mathrm{ppm})$ \\
\hline $\mathrm{EtO}_{2}{ }_{5 \mathrm{~b}}^{\mathrm{NC}} \prod_{\substack{\mathrm{N} \\
1 \\
\mathrm{CH}}}^{\mathrm{N}}$ & 3.99 & ${ }_{5 \mathrm{C}}^{\mathrm{EtO}_{2} \mathrm{C}} \prod_{1}^{\mathrm{CH}}$ & 3.94 \\
\hline${ }_{5 \mathrm{O}}{ }^{\mathrm{NC}} \prod_{\substack{\mathrm{N} \\
\mathrm{CH}_{3}}}^{\mathrm{N}}$ & 3.85 & $\mathrm{Se}^{\mathrm{HO}_{2} \mathrm{C}} \mathrm{I}^{\mathrm{N}}$ & 3.80 \\
\hline$\prod_{5 \mathrm{f}}^{\mathrm{NC}} \prod_{\substack{\mathrm{N} \\
1 \\
\mathrm{CH}_{3}}}^{\mathrm{N}}$ & 3.76 & & \\
\hline
\end{tabular}

Table 4. Chemical Shifts of $\mathrm{N}-\mathrm{CH}_{3}$ in 2-Amino-cyanoimidazole Derivatives

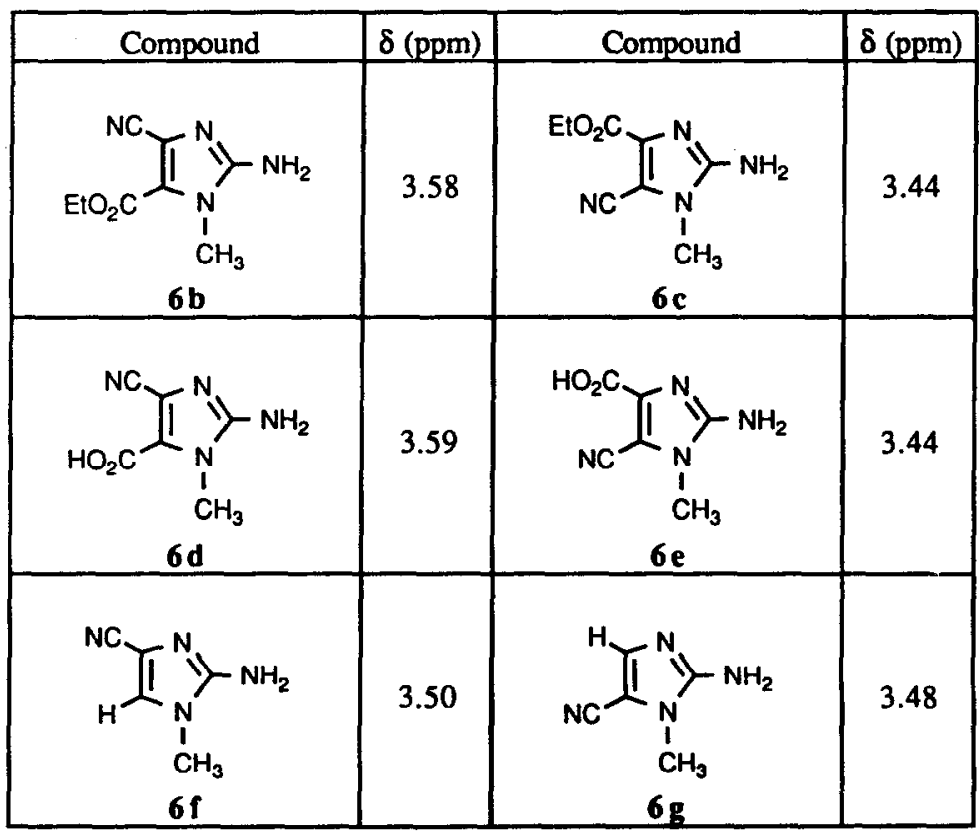


From the data listed in Tables 3 and 4, it may be seen that the 5-esters and 5-acids have a downfield chemical shift compared to the 4-esters and 4-acids. The regiochemistry of these compounds have already been established by NOE studies. The result of the NOE studies is consistent with the chemical shift differences for the $\mathrm{N}$-methyl groups. Therefore, this concept of the chemical shift differences may be applied to the 2-bromo derivatives. The chemical shifts of the N-methyl groups of the 2-bromo derivatives are listed in Table 5.

Table 5. $\mathrm{N}-\mathrm{CH}_{3}$ Chemical Shifts of 2-Bromo-cyanoimidazole Derivatives

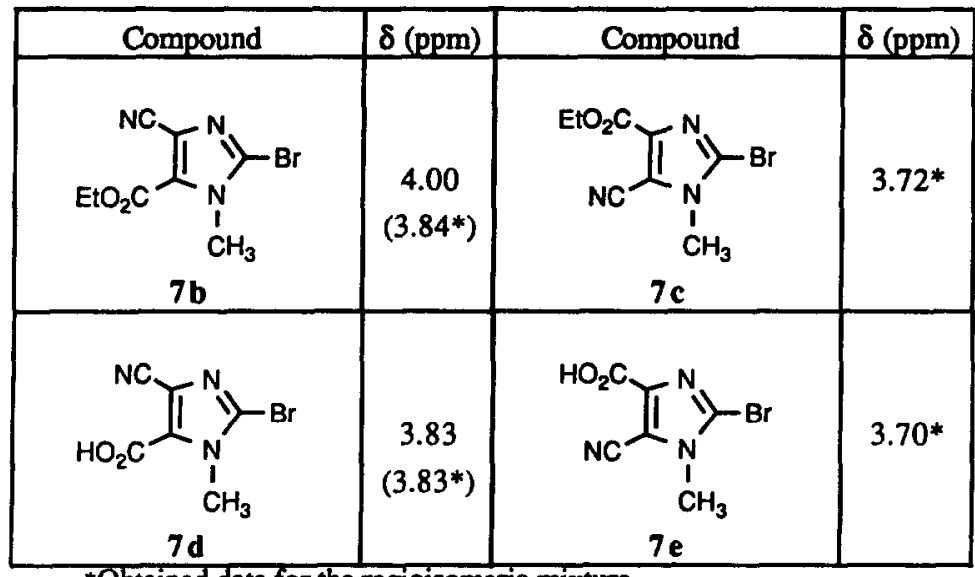

*Obtained data for the regioisomeric mixture

The chemical shifts of $7 \mathrm{~b}$ and $7 \mathrm{~d}$ appear downfield compared to their regioisomers $7 \mathrm{c}$ and $7 \mathrm{e}$, respectively. Therefore the compounds $7 \mathrm{~b}$ and $7 \mathrm{~d}$ must have the ester and the acid groups at the 5-position.

In conclusion, we have been able to synthesize new functionalized derivatives of dicyanoimidazoles such as monoesters and monoacids in addition to monocyanoimidazoles. ${ }^{28}$ Also, we have been able to assign the regiochemistry of these new compounds by NOE and also by the chemical shift differences of the N-methyl groups.

\section{EXPERIMENTAL}

\section{GENERAL PROCEDURE}

Melting points were recorded on a Mel-Temp apparatus and are uncorrected. Thin layer chromatography was accomplished on Eastman Kodak silica gel sheets containing fluorescent indicator. Column chromatography was performed using 230-400 mesh silica gel purchased from Aldrich Chemical Company, Inc. Infrared spectra were recorded using a Nicolet 5-DX FTIR spectrophotometer. ${ }^{1} \mathrm{H}$ NMR and ${ }^{13} \mathrm{C}$ NMR were recorded using Bruker AM-300 (300 MHz) or AM-360 (360 MHz) or AC-200 (200 MHz) spectrometers. Chemical shift values are reported relative to tetramethylsilane in appropriate solvents. All ${ }^{13} \mathrm{C}$ NMR spectra were done using broad band proton decoupling. Nominal mass spectra were recorded on a Finnigan model 4021 mass spectrometer. High resolution mass spectra were recorded on a VG analytical model 70-250S mass spectrometer. Elemental analyses were performed at University of Michigan on a Perkin-Elmer $2400 \mathrm{CHN}$ 
analyzer or by Oneida Research Services, Inc., Whitesboro, N.Y. Thermogravimetric analysis(TGA) was performed on a Perkin-Elmer 7/DX Thermal Analysis System. Solvents were purified and distilled under nitrogen prior to use.

\section{MONOETHANOLYSIS OF DICYANOIMIDAZOLES}

\section{Ethyl 4(5)-cyano-5(4)-imidazolecarboxylate(5a)4: Typical Procedure}

Into a solution of 4,5 -dicyanoimidazole $(5,1.937 \mathrm{~g}, 0.016 \mathrm{~mol})$ in ethanol $(10 \mathrm{~mL}, 95 \%)$ was added concentrated sulphuric acid $(0.44 \mathrm{~mL}, 8.261 \mathrm{mmol})$ and the reaction mixture was refluxed for $48 \mathrm{~h}$. The reaction mixture was cooled to room temperature and was poured into water $(20 \mathrm{~mL})$ when a white solid precipitated out. The solid obtained was dissolved in ethyl acetate $(20 \mathrm{~mL})$. The ethyl acetate solution was washed with brine and was dried over $\mathrm{MgSO}_{4}$. The organic solvent was removed in vacuum to yield a mixture of the crude product and the starting material $(1.623 \mathrm{~g})$. Fractional recrystallization of the mixture from watermethanol gave the product in the first crop $(0.541 \mathrm{~g}, 20 \%)$. TLC $\mathrm{R}_{\mathrm{f}} 0.12$ (EtOAc); $\mathrm{Mp} .181-183^{\circ} \mathrm{C}$; IR(KBr) $3134,3100-2800$ (br) $2242,1722,1488,1477,1453,1399,1379,1350,1321,1271,1256,1196,1159$, $1115,1086,1014,969,940,876,841,791,649,632,472 \mathrm{~cm}^{-1} ;{ }^{1} \mathrm{H}$ NMR(acetone-d 6$) \delta 8.03(\mathrm{~s}, 1 \mathrm{H})$, $4.37(\mathrm{q}, J=7 \mathrm{~Hz}, 2 \mathrm{H}), 1.33(\mathrm{t}, J=7 \mathrm{~Hz}, 3 \mathrm{H}) ;{ }^{13} \mathrm{C}$ NMR(acetone-d 6 ) $\delta 158.14,140.17,130.27,117.65,114.00$, $62.11,14.01 ; \mathrm{MS}(\mathrm{EI} / 70 \mathrm{eV}) \mathrm{m} / \mathrm{z}$ 165(28, $\left.\mathrm{M}^{+}\right), 137(100 \%), 119(79), 93(28), 65(40), 38(29)$; Hrms calcd for $\mathrm{C}_{7} \mathrm{H}_{7} \mathrm{~N}_{3} \mathrm{O}_{2}: 165.0538$; found 165.0540 .

\section{Ethyl 2-bromo-4(5)-cyano-5(4)-imidazolecarboxylate(7a)}

Reagents: 2-bromo-4,5-dicyanoimidazole $(7,2.028 \mathrm{~g}, 0.010 \mathrm{~mol})$, ethanol $(20 \mathrm{~mL}, 95 \%)$ and concentrated sulphuric acid $(0.55 \mathrm{~mL}, 0.010 \mathrm{~mol})$. Yield: $(1.011 \mathrm{~g}, 40 \%) ; \mathrm{Mp} 202-204^{\circ} \mathrm{C}$; IR(KBr) 3106 , $3024,3000,2924,2260,1732,1574,1481,1467,1409,1395,1386,1372,1351,1346,1272,1258,1195$, $1117,1102,1016,976,822,775,654 \mathrm{~cm}^{-1} ;{ }^{1} \mathrm{H} \mathrm{NMR}\left(\mathrm{CDCl}_{3}\right) \delta 10.7(\mathrm{br}, 1 \mathrm{H}), 4.5(\mathrm{q}, J=7 \mathrm{~Hz}, 2 \mathrm{H}), 1.4(\mathrm{t}, J=7$ $\mathrm{Hz}, 3 \mathrm{H}) ; \mathrm{MS}(\mathrm{EI} / 70 \mathrm{eV}) \mathrm{m} / \mathrm{z}$ 245(23, M+2), 243(24, $\left.\mathrm{M}^{+}\right), 217(76), 215(80), 199(95), 197(100 \%), 171(12)$, 145(8), 119(5), 108(15), 91(49), 78(11), 65(53), 38(62); Anal. calcd for $\mathrm{C}_{7} \mathrm{H}_{6} \mathrm{~N}_{3} \mathrm{O}_{2}{ }^{79} \mathrm{Br}: \mathrm{C}, 34.45, \mathrm{H}, 2.48$, $\mathrm{N}, 17.22$; found: $\mathrm{C}, 34.20, \mathrm{H}, 2.24, \mathrm{~N}, 17.45$.

\section{Ethyl 2-amino-4(5)-cyano-5(4)-imidazolecarboxylate(6a)}

A suspension of 2-amino-4,5-dicyanoimidazole $(6,31.44 \mathrm{~g}, 0.24 \mathrm{~mole})$ in ethanol $(95 \%, 120 \mathrm{~mL}, 2.16$ mol) was cooled to $0{ }^{\circ} \mathrm{C}$ in an ice bath and concentrated sulfuric acid ( $25 \mathrm{~mL}, 0.48$ mole) was slowly added dropwise. The reaction mixture was refluxed for 10 hours and was then cooled to room temperature. The reaction mixture was poured into ice water $(1.5 \mathrm{~L})$ and a white solid was formed upon standing. An additional amount of white solid was obtained by adjusting the $\mathrm{pH}$ to 3 with $\mathrm{KOH}$. The solid was filtered, washed with water and was dried in vacuum at $100^{\circ} \mathrm{C}$. Yield: $(17.02 \mathrm{~g}, 40 \%)$. The solid was crystallized from water to give colorless needles. Yield: (15.56 g, 37\%); Mp 258-260 ${ }^{\circ} \mathrm{C}$; TLC $R_{\mathrm{f}}$ 0.06(EtOAc); IR(KBr) 3450, 3405, 3100$2600(\mathrm{br}), 2237,1711,1653 \mathrm{~cm}^{-1}$ (identical to the values given in literature ${ }^{25 a}$ ); ${ }^{1} \mathrm{H}$ NMR (DMSO-d 6 ) $\delta 12.3$ 11.9 (br, $1 \mathrm{H}), 6.14(\mathrm{~s}, 2 \mathrm{H}), 4.28-4.21(\mathrm{q}, J=7 \mathrm{~Hz}, 2 \mathrm{H}), 1.29-1.24(\mathrm{t}, J=7 \mathrm{~Hz}, 3 \mathrm{H})$. 


\section{METHYLATION OF ETHYL CYANOIMIDAZOLECARBOXYLATES}

\section{Ethyl 4(5)-cyano-1-methyl-5(4)-imidazolecarboxylate(5b \& 5c): regioisomeric mixture}

Sodium hydride $(60 \% \mathrm{w} / \mathrm{w}$ in mineral oil, $0.044 \mathrm{~g}, 1.100 \mathrm{mmol})$ was washed under nitrogen with hexane in a $25 \mathrm{~mL}$ flask to remove the mineral oil present and was suspended in $\mathrm{N}, \mathrm{N}$-dimethyl formamide (DMF, $1.0 \mathrm{~mL}$ ). The reaction mixture was cooled to $0{ }^{\circ} \mathrm{C}$ and a solution of ethyl $4(5)$-cyano-5(4)imidazolecarboxylate $(5 \mathrm{a}, 0.180 \mathrm{~g}, 1.091 \mathrm{mmol})$ in DMF $(2.0 \mathrm{~mL})$ was added to the reaction mixture dropwise and the reaction mixture was stirred for $30 \mathrm{~min}$. Hydrogen gas evolution was observed at the end of which dimethyl sulfate $(0.12 \mathrm{~mL}, 1.268 \mathrm{mmol})$ was added to the reaction mixture dropwise. The reaction mixture was gradually warmed to room temperature and the stirring was continued overnight. The reaction mixture was poured into water and the aqueous layer was extracted with dichloromethane $(10 \mathrm{~mL} \times 4)$. The organic extract was washed with $0.1 \mathrm{M}$ ammonium hydroxide solution followed by brine. The organic extract was dried over $\mathrm{MgSO}_{4}$ and the solvent was evaporated in vacuum to give the product as the isomeric mixture $(0.089 \mathrm{~g}, 46 \%)$. TLC Rfs 0.49 \& 0.25(EtOAc); Mp 42-44 ${ }^{\circ} \mathrm{C}$; IR(KBr) 3116, 3095, 2993, 2240, $1726 \mathrm{~cm}^{-1}$; Anal. calcd for $\mathrm{C}_{8} \mathrm{H}_{9} \mathrm{~N}_{3} \mathrm{O}_{2} \cdot 0.25 \mathrm{H}_{2} \mathrm{O}: \mathrm{C}, 52.31, \mathrm{H}, 5.21, \mathrm{~N}, 22.88$; found: $\mathrm{C}, 52.34, \mathrm{H}, 5.00, \mathrm{~N}, 22.96$. The regioisomers were separated by column chromatography using ethyl acetate as the eluent and $230-400$ mesh silica gel.

\section{Elhyl 4-cyano-1-methyl-5-imidazolecarboxylate(5b)}

TLC $R_{f}$ 0.58(EtOAC); Mp 56-58 ${ }^{\circ} \mathrm{C}$; IR(KBr) 3117, 2995, 2242, 1726, $1531,1512 \mathrm{~cm}^{-1} ;{ }^{1} \mathrm{H}$ NMR(acetone-d 6$) \delta 7.93(\mathrm{~s}, 1 \mathrm{H}), 4.37(\mathrm{q}, J=7 \mathrm{~Hz}, 2 \mathrm{H}), 3.99(\mathrm{~s}, 3 \mathrm{H}), 1.38(\mathrm{t}, J=7 \mathrm{~Hz}, 3 \mathrm{H}) ;{ }^{13} \mathrm{C}$ NMR(acetoned6) $\delta 142.81,141.37,110.73,110.62,61.57,61.04,36.65,14.42 ; \mathrm{MS}(\mathrm{EI} / 70 \mathrm{eV}) \mathrm{m} / \mathrm{z} 179\left(60, \mathrm{M}^{+}\right), 151(57)$, 134(100\%), 107(66), 80(63), 52(70), 42(40).

\section{Ethyl 5-cyano-1-methyl-4-imidazolecarboxylate(5c)}

TLC Rf 0.32(EtOAc); Mp 112-114 ${ }^{\circ} \mathrm{C}$; IR(KBr) 3102, 2995, 2237, 1725, 1533, $1507 \mathrm{~cm}^{-1}$; ${ }^{1} \mathrm{H}$ NMR(acetone-d 6 ) $\delta 7.95(\mathrm{~s}, 1 \mathrm{H}), 4.33(\mathrm{q}, J=7 \mathrm{~Hz}, 2 \mathrm{H}), 3.94(\mathrm{~s}, 3 \mathrm{H}), 1.38\left(\mathrm{t}, J=7 \mathrm{~Hz}, 3 \mathrm{H}\right.$ ); ${ }^{13} \mathrm{C}$ NMR(acetone$\left.\mathrm{d}_{6}\right) \delta 158.70,144.35,129.8,120.23,114.83,62.33,35.20,14.26 ; \mathrm{MS}(\mathrm{EI} / 70 \mathrm{eV}) \mathrm{m} / \mathrm{z}$ 179(28, $\left.\mathrm{M}^{+}\right), 151(27)$, 134(100\%), 107(69), 82(28), 52(22), 42(76).

\section{Ethyl 2-amino-4(5)-cyano-1-methyl-5(4)-imidazolecarboxylate(6b \& 6c): regioisomeric mixture}

Sodium hydride (60\% dispersion in mineral oil, $2.29 \mathrm{~g}, 57.3 \mathrm{mmol})$ was rinsed with hexanes $(2 \times 10$ $\mathrm{mL}$ ) under nitrogen in a $200 \mathrm{~mL}$ flask and was cooled to $0{ }^{\circ} \mathrm{C}$. A solution of ethyl 2-amino-4(5)-cyano-5(4)imidazolecarboxylate $(6 \mathrm{a}, 10.20 \mathrm{~g}, 56.7 \mathrm{mmol})$ in DMF $(75 \mathrm{~mL})$ was added to the sodium hydride slowly. The evolution of hydrogen was observed and the solution was stirred at $0^{\circ} \mathrm{C}$ for $30 \mathrm{~min}$. Dimethyl sulfate $(5.5 \mathrm{ml}$, $56.7 \mathrm{mmol}$ ) was added to the reaction mixture dropwise. The reaction mixture was allowed to warm to room temperature over $12 \mathrm{~h}$. The reaction mixture was poured into water $(400 \mathrm{~mL})$ and a white precipitate was formed. The white solid was filtered, rinsed with water and dried to yield a regioisomeric mixture. Yield: 4.24 $\mathrm{g}(39 \%)$. The aqueous mother liquor was allowed to stand and yielded another batch of a regioisomeric mixture $(2.67 \mathrm{~g}, 63 \%$ overall). The $4.24 \mathrm{~g}$ fraction of solid was recrystallized from water to yield ethyl 2-amino-4cyano-1-methyl-5-imidazolecarboxylate(6b). Yield: $2.81 \mathrm{~g}$. The mother liquor yielded an additional batch of regioisomeric mixture $(0.81 \mathrm{~g})$. The $2.67 \mathrm{~g}$ fraction was placed in isopropanol and was heated. The insoluble 
fraction was filtered to yield ethyl 2-amino-5-cyano-1-methyl-4-imidazolecarboxylate (6c, $1.47 \mathrm{~g}$ ). The mother liquor yielded an additional batch of regioisomeric mixture $(0.71 \mathrm{~g})$. The compound $6 \mathrm{c}$ was recrystallized from a large excess of isopropanol.

6b: $\quad$ TLC $R_{f}$ 0.60(4:1 EtOAc/MeOH); Mp 235-237 ${ }^{\circ} \mathrm{C}$; $\operatorname{IR}(\mathrm{KBr}) 3415,3328,3147,2242,1705$, $1661,1576,1130 \mathrm{~cm}^{-1}$; ${ }^{1} \mathrm{H}$ NMR(DMSO-d 6$) \delta 6.66(\mathrm{~s}, 2 \mathrm{H}), 4.31-4.23(\mathrm{q}, J=7 \mathrm{~Hz}, 2 \mathrm{H}), 3.58(\mathrm{~s}, 3 \mathrm{H}), 1.32-$ $1.27(\mathrm{t}, J=7 \mathrm{~Hz}, 3 \mathrm{H}) ;{ }^{13} \mathrm{C}$ NMR(DMSO-d 6 ) $\delta 157.94,154.15,123.41,116.51,115.23,60.66,31.12,13.86$; $\mathrm{MS}(\mathrm{EI} / 70 \mathrm{eV}) \mathrm{m} / \mathrm{z} 194\left(\mathrm{M}^{+}\right), 166,149,122,80,42(100 \%)$; Anal calcd for $\mathrm{C}_{8} \mathrm{H}_{10} \mathrm{~N}_{4} \mathrm{O}_{2}: \mathrm{C}, 49.47, \mathrm{H}, 5.20, \mathrm{~N}$, 28.85; found $\mathrm{C}, 49.51, \mathrm{H}, 4.80, \mathrm{~N}, 28.70$.

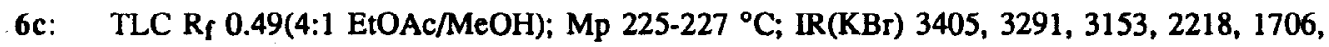
$1639,1568 \mathrm{~cm}^{-1} ;{ }^{1} \mathrm{H}$ NMR(DMSO-d 6 ) $\delta 6.67(\mathrm{~s}, 2 \mathrm{H}), 4.28-4.21(\mathrm{q}, J=7 \mathrm{~Hz}, 2 \mathrm{H}), 3.44(\mathrm{~s}, 3 \mathrm{H}), 1.29-1.24(\mathrm{t}$, $J=7 \mathrm{~Hz}, 3 \mathrm{H}$ ); ${ }^{13} \mathrm{C}$ NMR(DMSO-d 6$) \delta 160.33,152.40,137.56,111.59,103.41,60.30,30.51,13.91$; $\mathrm{MS}(\mathrm{El} / 70 \mathrm{eV}) \mathrm{m} / \mathrm{z} 194\left(\mathrm{M}^{+}\right), 166,149,122,80,42(100 \%)$; Anal calcd for $\mathrm{C}_{8} \mathrm{H}_{10} \mathrm{~N}_{4} \mathrm{O}_{2}: \mathrm{C}, 49.47, \mathrm{H}, 5.20, \mathrm{~N}$, 28.85; found C, 49.26, H, 5.16, N, 28.60 .

\section{Ethyl 2-bromo-4-cyano-1-methyl-5-imidazolecarboxylate(7b)}

Method $A^{22}$

Into a suspension of ethyl 2-bromo-4(5)-cyano-5(4)-imidazolecarboxylate (7a, $0.206 \mathrm{~g}, 0.848 \mathrm{mmol})$ in water $(3.0 \mathrm{~mL})$ was added sodium bicarbonate $(0.107 \mathrm{~g}, 1.274 \mathrm{mmol})$ and the reaction mixture was gradually heated to $60^{\circ} \mathrm{C}$ in an hour. After the evolution of $\mathrm{CO}_{2}(\mathrm{~g})$, dimethyl sulfate $(0.16 \mathrm{~mL}, 1.691 \mathrm{mmol})$ was added to the reaction mixture dropwise over a period of one hour. The reaction mixture was stirred for six hours at $60^{\circ} \mathrm{C}$, The reaction mixture was poured into water $(20 \mathrm{~mL})$. The aqueous layer was extracted with ethyl acetate $(10 \mathrm{~mL}$ $x$ 4). The organic layer was washed with $0.1 \mathrm{M}$ sodium bicarbonate solution followed by brine. The ethyl acetate extract was dried over $\mathrm{MgSO}_{4}$ and the solvent was evaporated in vacuum to yield a white fluffy solid of the regioisomeric mixture $(0.153 \mathrm{~g}, 70 \%)$. TLC of the mixture: $\mathrm{Rfs} 0.64(\mathrm{EtOAc}) ;\left(0.36 \& 0.21\left(\mathrm{CH}_{2} \mathrm{Cl}_{2}\right)\right.$ ); The 5-ester (7b) was isolated from the regioisomer by fractional crystallization from water/acetone in the first crop.

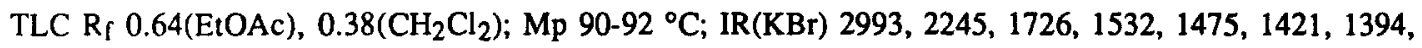
$1386,1372,1349,1336,1307,1283,1270,1235,1159,1147,1101,1049,1012,872,846,775,761,656$ $\mathrm{cm}^{-1} ;{ }^{1} \mathrm{H} \mathrm{NMR}\left(\mathrm{CDCl}_{3}\right) \delta 4.31(\mathrm{q}, J=7 \mathrm{~Hz}, 2 \mathrm{H}), 3.87(\mathrm{~s}, 3 \mathrm{H}), 1.32(\mathrm{t}, J=7 \mathrm{~Hz}, 3 \mathrm{H}) ;{ }^{13} \mathrm{C} \mathrm{NMR}\left(\mathrm{CDCl}_{3}\right) \delta$ $156.81,130.68,127.59,119.66,112.51,104.20,62.13,35.06,13.64 ; \mathrm{MS}(\mathrm{EI} / 70 \mathrm{eV}) \mathrm{m} / \mathrm{z} 259(94, \mathrm{M}+2)$, 257(100\%, $\left.\mathrm{M}^{+}\right), 231(79), 229(84), 214(74), 212(78), 187(58), 185(62), 150(36), 122(36), 105(80), 80(53)$, 52(58), 42(23); Anal. calcd for $\mathrm{C}_{8} \mathrm{H}_{8} \mathrm{~N}_{3} \mathrm{O}_{2}{ }^{79} \mathrm{Br}$ : $\mathrm{C}, 37.23, \mathrm{H}, 3.12, \mathrm{~N}, 16.28$; found: $\mathrm{C}, 37.35, \mathrm{H}, 3.11, \mathrm{~N}$, 16.34 .

\section{Method $B$}

Into a solution of ethyl 2-bromo-4(5)-cyano-5(4)-imidazolecarboxylate $(7 \mathrm{a}, 0.058 \mathrm{~g}, 0.237 \mathrm{mmol})$ in THF $(2.0 \mathrm{~mL})$ was added triethylamine $(0.03 \mathrm{~mL}, 0.216 \mathrm{mmol})$ dropwise under nitrogen. The reaction mixture was cooled to $0{ }^{\circ} \mathrm{C}$ and dimethyl sulfate $(0.01 \mathrm{~mL}, 0.106 \mathrm{mmol})$ was added to the reaction mixture dropwise and the reaction mixture was stirred for three days under nitrogen at room temperature. The reaction mixture was poured into water $(20 \mathrm{~mL})$ and the aqueous layer was extracted with dichloromethane $(10 \mathrm{~mL} \times 4)$. The organic layer was washed with brine and was subsequently dried over $\mathrm{MgSO}_{4}$. The dichloromethane was removed from the organic layer in vacuum when the solid product was obtained as the regioisomeric mixture $(0.046 \mathrm{~g}$, 
75\%). Fractional crystallization of the crude product from water/acetone mixture gave the 5-ester $(\mathbf{7 b})$ in the first crop. TLC Rf 0.62(EtOAc), 0.40( $\left.\mathrm{CH}_{2} \mathrm{Cl}_{2}\right)$; $\mathrm{Mp} 90-92^{\circ} \mathrm{C}$; IR(KBr) 2993, 2245, 1726, 1532, 1475, 1421, $1394,1386,1372,1349,1336,1307,1283,1270,1235,1159,1147,1101,1049,1012,872,846,775,761$, $656 \mathrm{~cm}^{-1} ;{ }^{1} \mathrm{H} \mathrm{NMR}\left(\mathrm{CDCl}_{3}\right) \delta 4.45(\mathrm{q}, J=7 \mathrm{~Hz}, 2 \mathrm{H}), 4.0(\mathrm{~s}, 3 \mathrm{H}), 1.4(\mathrm{t}, J=7 \mathrm{~Hz}, 3 \mathrm{H})$; Anal. calcd for $\mathrm{C}_{8} \mathrm{H}_{8} \mathrm{~N}_{3} \mathrm{O}_{2}{ }^{79} \mathrm{Br}: \mathrm{C}, 37.23, \mathrm{H}, 3.12, \mathrm{~N}, 16.28$; found: $\mathrm{C}, 37.44, \mathrm{H}, 3.09, \mathrm{~N}, 16.10$.

[For the regioisomeric mixture(7b \& 7c): ${ }^{1} \mathrm{H}$ NMR( $\left.\mathrm{CDCl}_{3}\right) \delta 4.29(\mathrm{q}, J=7 \mathrm{~Hz}, 3 \mathrm{H}), 3.84(\mathrm{~s}, 3 \mathrm{H})$, $3.72(\mathrm{~s}, 2 \mathrm{H}), 1.29(\mathrm{t}, J=7 \mathrm{~Hz}, 5 \mathrm{H}) ;{ }^{13} \mathrm{C} \mathrm{NMR}\left(\mathrm{CDCl}_{3}\right) \delta 158.91,156.76,140.37,130.62,127.54,125.52$, $119.60,112.47,111.47,108.81,62.08,61.65,35.01,34.38,13.78,13.59]$

\section{HYDROLYSIS OF ETHYL N-METHYL-CYANOIMIDAZOLECARBOXYLATES}

\section{2-Amino-4-cyano-1-methyl-5-imidazolecarboxylic acid(6d): Typical Procedure}

Ethyl 2-amino-4-cyano-1-methyl-5-imidazolecarboxylate $(6 \mathrm{~b}, 2.25 \mathrm{~g}, 11.2 \mathrm{~mol})$ was suspended in water $(20 \mathrm{~mL})$. Tetraethylammonium hydroxide $(40 \%$ in water, $4.6 \mathrm{~mL}, 11.3 \mathrm{mmol}$ ) was added to the reaction mixture dropwise and the reaction mixture was heated to $70-80^{\circ} \mathrm{C}$ for 30 minutes. The reaction mixture was cooled, filtered and the filtrate was acidified to $\mathrm{pH}=1$ with $\mathrm{HCl}$ to give a white precipitate which was filtered, rinsed with acetone and ether, respectively. Yield: (1.67 g, 87\%). Mp 212-214 ${ }^{\circ} \mathrm{C}$ (dec.); IR(KBr) 3396,3196 , $2251,1656,1573,1062,788 \mathrm{~cm}^{-1}$; ${ }^{1} \mathrm{H}$ NMR(DMSO-d 6$) \delta 6.58(\mathrm{~s}, 2 \mathrm{H}), 3.59\left(\mathrm{~s}, 3 \mathrm{H}\right.$ ); ${ }^{13} \mathrm{C}$ NMR(DMSO-d 6$) \delta$ $159.51,153.98,124.99,116.17,115.58,31.08 ; \mathrm{MS}(\mathrm{EI} / 70 \mathrm{eV}) \mathrm{m} / \mathrm{z} \quad 166\left(\mathrm{M}^{+}\right), 122(100 \%), 121,86,44,42$; Anal. calcd for $\mathrm{C}_{6} \mathrm{H}_{6} \mathrm{~N}_{4} \mathrm{O}_{2}$ : C, 43.38, $\mathrm{H}, 3.64, \mathrm{~N}, 33.72$; found: $\mathrm{C}, 43.20, \mathrm{H}, 3.62, \mathrm{~N}, 33.64$.

\section{2-Amino-5-cyano-1-methyl-4-imidazolecarboxylic acid(6e)}

Reagents: Ethyl 2-amino-5-cyano-1-methyl-4-imidazolecarboxylate $(6 \mathrm{c}, 3.290 \mathrm{~g}, 16.9 \mathrm{mmol})$ and tetraethylammonium hydroxide ( $40 \% \mathrm{w} / \mathrm{w}, 6.1 \mathrm{~mL}, 17.0 \mathrm{mmol}) ;$ Yield $(2.04 \mathrm{~g}, 72 \%)$; $\mathrm{Mp} 208-210^{\circ} \mathrm{C}(\mathrm{dec}$ ); IR(KBr) 3346, 3340, 2233, 1680, 1641, 1343, $977 \mathrm{~cm}^{-1} ;{ }^{1} \mathrm{H}$ NMR(DMSO-d 6 ) $\delta 6.66(\mathrm{~s}, 2 \mathrm{H}), 3.44(\mathrm{~s}, 3 \mathrm{H})$; $\left.{ }^{13} \mathrm{C} \mathrm{NMR(DMSO-d}\right) \delta 161.67,152.56,138.65,111.84,103.16,30.42 ; \mathrm{MS}(\mathrm{EI} / 70 \mathrm{eV}) \mathrm{m} / \mathrm{z} 166\left(\mathrm{M}^{+}\right), 122$, $121,53,44(100 \%), 42 ; \mathrm{Hrms}$ calcd for $\mathrm{C}_{6} \mathrm{H}_{6} \mathrm{~N}_{4} \mathrm{O}_{2}$ : 166.0491 ; found 166.0495 .

\section{4-Cyano-1-methyl-5-imidazolecarboxylic acid(5d): Typical Procedure}

Ethyl 4-cyano-1-methyl-5-imidazolecarboxylate $(5 \mathrm{~b}, 0.609 \mathrm{~g}, 3.402 \mathrm{mmol})$ was suspended in water $(2.0 \mathrm{~mL})$ and tetraethylammonium hydroxide $(40 \% \mathrm{w} / \mathrm{w}, 1.22 \mathrm{~mL}, 3.391 \mathrm{mmol})$ was added to it at room temperature. The reaction mixture was stirred for 30 minutes when a homogeneous solution was obtained. The solution was filtered and the filtrate was acidified using concentrated hydrochloric acid to $\mathrm{pH} \approx 1$ when a white solid of the acid precipitated out. The acid was filtered, washed with water and dried. Yield $(0.446 \mathrm{~g}, 87 \%)$; Mp 204-206 ${ }^{\circ} \mathrm{C}$ (dec.); IR(KBr) 3115, 2248, 1705, $1563 \mathrm{~cm}^{-1}$; ${ }^{1} \mathrm{H}$ NMR(DMSO-d 6$) 83.85(\mathrm{~s}, 3 \mathrm{H}), 8.06(\mathrm{~s}$, $1 \mathrm{H}) ;{ }^{13} \mathrm{C}$ NMR(DMSO-d 6 ) $\delta 158.91,143.74,130.01,117.99,114.49,34.54 ; \mathrm{MS}(\mathrm{EI} / 70 \mathrm{eV}) \mathrm{m} / \mathrm{z} 151\left(\mathrm{M}^{+}\right)$, 134(41), 107(57), 79(10), 67(19) 52(16), 42(100\%); Hrms calcd for $\mathrm{C}_{6} \mathrm{H}_{5} \mathrm{~N}_{3} \mathrm{O}_{2}: 151.0382$; found 151.0386 .

\section{5-Cyano-1-methyl-4-imidazolecarboxylic acid(5e)}

Reagents: Ethyl 5-cyano-1-methyl-4-imidazolecarboxylate $(5 \mathrm{c}, 0.237 \mathrm{~g}, 1.324 \mathrm{mmol})$ and tetraethylammonium hydroxide $(40 \% \mathrm{w} / \mathrm{w}, 0.48 \mathrm{~mL}, 1.334 \mathrm{mmol})$; Yield $(0.173 \mathrm{~g}, 86 \%)$; Mp 236-238 ${ }^{\circ} \mathrm{C}$ (subl.); IR(KBr) $3117,2234,1709,1501 \mathrm{~cm}^{-1} ;{ }^{1} \mathrm{H}$ NMR(DMSO-d 6$) \delta 3.80(\mathrm{~s}, 3 \mathrm{H}), 8.07(\mathrm{~s}, 1 \mathrm{H}) ;{ }^{13} \mathrm{C}$ NMR(DMSO-d 6$) \delta 161.44,142.33,140.94,110.45,108.99,33.11 ; \mathrm{MS}(\mathrm{EI} / 70 \mathrm{eV}) \mathrm{m} / \mathrm{z} 151\left(100 \%, \mathrm{M}^{+}\right)$, 
134(38), 133(40), 107(29), 79(30), 52(11), 42(14); Anal. calcd for $\mathrm{C}_{6} \mathrm{H}_{5} \mathrm{~N}_{3} \mathrm{O}_{2}$ : C, 47.68, H, 3.31, N, 27.81; found: $\mathrm{C}, 47.63, \mathrm{H}, 3.43, \mathrm{~N}, 27.48$.

\section{2-Bromo-4-cyano-1-methyl-5-imidazolecarboxylic acid(7d)}

Reagents: Ethyl 2-bromo-4-cyano-1-methyl-5-imidazolecarboxylate (7b, $0.375 \mathrm{~g}, 1.459 \mathrm{mmol})$ and tetraethylammonium hydroxide (40\% w/w, $0.53 \mathrm{~mL}, 1.473 \mathrm{mmol}) ;$ Yield $(0.263 \mathrm{~g}, 79 \%)$; Mp 184-186 ${ }^{\circ} \mathrm{C}\left(\right.$ dec.); IR(KBr) 2243, 1704, 1566, 1463, 1419, 1366, 1341, 1311, 1243, 1146, 1113, 1051, $766 \mathrm{~cm}^{-1}$; ${ }^{1} \mathrm{H}$ NMR(DMSO-d6) 8 3.83(s, 3H); ${ }^{13}$ C NMR(DMSO-d6) $\delta 158.27,132.59,128.17,118.12,113.69,35.28$; $\mathrm{MS}(\mathrm{EI} / 70 \mathrm{eV}) \mathrm{m} / \mathrm{z} 231(61, \mathrm{M}+2), 229\left(64, \mathrm{M}^{+}\right), 187(77), 185(84), 150(43), 122(42), 105(78), 79(60), 52(69)$, 42(100\%), 38(43); Hrms. calcd for $\mathrm{C}_{6} \mathrm{H}_{4} \mathrm{~N}_{3} \mathrm{O}_{2} 79 \mathrm{Br}: 228.9487$; found: 228.9477.

[For the regioisomeric mixture(7d \& 7e): IR(KBr) 2912, 2246, 2238, 1734, 1715, 1480, 1465, 1384, $1372,1305,1256,1146,1109,761 \mathrm{~cm}^{-1} ;{ }^{1} \mathrm{H}$ NMR(DMSO-d 6$) \delta 3.83(\mathrm{~s}, 12 \mathrm{H}), 3.70(\mathrm{~s}, 3 \mathrm{H}) ;{ }^{13} \mathrm{C}$ NMR(DMSO-d 6 ) $\delta 160.12,158.30,140.84,132.73,128.09,126.15,118.09113 .72,111.54,110.03$, 35.27, 34.74; MS(EI/70 eV) m/z 231(92, M+2), 229(97, $\left.\mathrm{M}^{+}\right), 214(28), 213(35), 212(30), 211(34), 187(56)$, $185(63), 150(56), 122(75), 120(64), 105(100 \%), 79(64), 52(73), 42(61), 38(51)]$

\section{THERMAL DECARBOXYLATION EXPERIMENTS}

\section{4-Cyano-1-methylimidazole(5f): Typical procedure}

4-Cyano-1-methyl-5-imidazolecarboxylic acid $(5 \mathrm{~d}, 0.247 \mathrm{~g}, 1.636 \mathrm{mmol})$ was heated in a sand bath, preheated to $210-220^{\circ} \mathrm{C}$, for 5 minutes. Evolution of carbon dioxide was observed. The test tube was cooled to room temperature and the solid obtained was dissolved in acetone. The acetone solution was heated with carbon black to remove the color. The acetone solution was filtered and was evaporated to give colorless solid ( 0.126 g, 72\%). TLC Rf 0.32(EtOAc); Mp 64-66 ${ }^{\circ} \mathrm{C}$; IR(KBr) 3134, 3118, 3065, 2231, $1541 \mathrm{~cm}^{-1}$; ${ }^{1} \mathrm{H} \mathrm{NMR(CDCl} 3$ ) $\delta 7.47(\mathrm{~s}, 1 \mathrm{H}), 7.44(\mathrm{~s}, 1 \mathrm{H}), 3.76(\mathrm{~s}, 3 \mathrm{H}) ;{ }^{13} \mathrm{C} \mathrm{NMR}\left(\mathrm{CDCl}_{3}\right) \delta$ 139.30, 128.49, $114.68(2$ peaks), 34.02; $\mathrm{UV} / \mathrm{Vis}\left(\mathrm{CH}_{3} \mathrm{CN}\right) \lambda_{\max }$ (e) $205.60(16,920) ; \mathrm{MS}(\mathrm{EI} / 70 \mathrm{eV}) \mathrm{m} / \mathrm{z}$ 107(100\%, $\left.\mathrm{M}^{+}\right), 79(7), 66(14), 52(16)$, 42(84), 38(10); Anal. calcd for $\mathrm{C}_{5} \mathrm{H}_{5} \mathrm{~N}_{3} \cdot 0.3 \mathrm{H}_{2} \mathrm{O}: \mathrm{C}, 53.38, \mathrm{H}, 4.98, \mathrm{~N}, 37.37$; found: $\mathrm{C}, 53.02, \mathrm{H}, 4.45, \mathrm{~N}$, 37.03 .

\section{2-Amino-4-cyano-1-methylimidazole(6f)}

Reagent: 2-amino-4-cyano-1-methyl-5-imidazolecarboxylic acid (6d, $0.05 \mathrm{~g}, 0.5 \mathrm{mmol})$; Yield: $(0.03 \mathrm{~g}$, 69\%). TLC Rf 0.32(EtOAc); Mp 188-190 ${ }^{\circ} \mathrm{C}$; IR(KBr) 3397, 3148, 2228, 1660, $1582 \mathrm{~cm}^{-1}$; ${ }^{1} \mathrm{H}$ NMR(acetoned6) $\delta 7.37(\mathrm{~s}, 1 \mathrm{H}), 5.54(\mathrm{~s}, 2 \mathrm{H}), 3.50(\mathrm{~s}, 3 \mathrm{H}) ;{ }^{13} \mathrm{C}$ NMR(DMSO-d 6$) \delta 150.68,125.45,116.63,106.51,31.53$; $\mathrm{MS}(\mathrm{EI} / 70 \mathrm{eV}) \mathrm{m} / \mathrm{z} 122\left(\mathrm{M}^{+}\right), 121,94,86,53,42(100 \%)$; Anal. calcd for $\mathrm{C}_{5} \mathrm{H}_{6} \mathrm{~N}_{4}: \mathrm{C}, 49.17, \mathrm{H}, 4.95, \mathrm{~N}$, 45.87; found: C, 49.10, H, 4.78, N, 45.41 .

\section{2-Amino-5-cyano-1-methylimidazole $(6 \mathrm{~g})$}

Reagent: 2-amino-5-cyano-1-methyl-4-imidazolecarboxylic acid (6e, $0.17 \mathrm{~g}, 1.00 \mathrm{mmol})$; Yield: $(0.070$ g, 58\%);TLC Rf 0.22(EtOAC); $M p 210-212^{\circ} \mathrm{C}$; $\mathbb{R}(\mathrm{KBr}) 3335,3312,3192,2212,1655,1568,1191 \mathrm{~cm}^{-1} ;{ }^{1} \mathrm{H}$ NMR(acetone- $\left.\mathrm{d}_{6}\right) \delta 7.28(\mathrm{~s}, 1 \mathrm{H}), 5.78(\mathrm{~s}, 2 \mathrm{H}), 3.48(\mathrm{~s}, 3 \mathrm{H})$; ${ }^{13} \mathrm{C}$ NMR(DMSO-d 6 ) $\delta 152.68,137.86,113.11$, 98.59, 29.75; MS(EI/70eV) $\mathrm{m} / \mathrm{z} 122\left(\mathrm{M}^{+}\right), 121,94,86,53,42(100 \%)$; Hrms caled for $\mathrm{C}_{5} \mathrm{H}_{6} \mathrm{~N}_{4}: 122.0592$; found 122.0597 . 


\section{NUCLEAR OVERHAUSER EFTECT (NOE) EXPERIMENT}

Sample preparation: A solution of 4-cyano-1-methylimidazole(5f) in acetone-d6 $(10 \mathrm{mg} / \mathrm{mL})$ was placed in the NMR tube and was degassed for 15 minutes. The NMR tube was back filled with nitrogen.

\section{4-Cyano-1-methylimidazole(5f): General procedure.}

The NOE experiment was carried out by irradiating the methyl protons at $\delta 3.76$ and monitoring the enhancement of the aromatic protons at $\delta 7.47$ and 7.44. The NOE difference spectrum indicate an enhancement of $16 \%$ and $23 \%$ (2-3\% experimental error) for the aromatic protons. This result indicates that the cyano substitution is at the 4 position of the imidazole ring and assigned the structure of the regioisomer to be 4-cyano1-methylimidazole.

\section{REFERENCES AND NOTES}

1. (a) Apen, P. G.; Rasmussen, P. G. Heterocycles 1989, 29, 1325; (b) Apen, P. G.; Rasmussen, P. G. J. Heterocyclic Chem. 1993, 25, 43; (c) Allan, D. S.; Rasmussen, P. G. Synthetic Metals 1988, 25 , 139; (d) Apen, P. G.; Rasmussen, P. G. J. Am. Chem. Soc. 1992, 113, 6178.

2. Patel, N. R. U.S. Patent US 3,882,140 1980; Chem. Abstr. 1980, 93, 232722k.

3. Hashimoto, S.; Nakada, A.; Kano, S; Takahashi, S. Ger. Offen. 2,535,512, 1976; Chem. Abstr. $1976,85,33010 \mathrm{~m}$.

4. (a) Jpn. Kokai Tokkyo Koho JP 59,226,050 1984; Chem. Abstr. 1985, 102, 186656w; (b) Carlson, B. A. U.S. Patent. US 4,083,843 1978; Chem. Abstr. 1978, 89, 112352k.

5. (a) MacDonald, R. N.; Cairncross, A.; Sieja, J. B.; Sharkey, W. H. J. Polym. Sci., Polym. Chem. Ed. 1974, 12, 664; (b) Bouck, K. J., Ph.D. Thesis, The University of Michigan, Ann Arbor 1992; (c) Bouck, K. J.; Rasmussen, P. G. Macromolecules 1993, 26, 2077.

6. (a) Rasmussen, P. G.; Kolowich, J. B.; Bayón, J. C. J. Am. Chem. Soc. 1988, 110, 7042; (b) Rasmussen, P. G.; Anderson, J. G.; Bayón, J. C. Inorg. Chim. Acta 1984, 87, 159; (c) Rasmussen, P. G.; Bayón, J. C. Inorg. Chim. Acta 1984, 81, 115.

7. (a) Thurber, E. L.; Subrayan, R. P.; Rasmussen, P. G. Contemporary Topics in Polymer Science, Plenum Press, New York, N.Y., 1992, 7, pp. 95-102; (b) Allan, D. S.; Thurber, E. L.; Apen, P.G.; Kim, Y. -K.; Subrayan, R. P.; Francis, A. H.; Rasmussen, P. G. Proceedings of the ACS division of Polymeric Materials: Science \& Engineering 1989, 61, 335; (c) Allan, D. S.; Rasmussen, P. G. J. Polym. Sci.: Part A: Polym. Chem. Ed. 1992, 30, 1413; (d) Thurber, E. L.; Rasmussen, P. G. J. Polym. Sci.: Part A: Polym. Chem. Ed. 1993, 31, 351. 
8. Brown, T.; Jones, J. H.; Wallis, J. D. J. Chem. Soc., Perkin Tans 1982, 3045; (b) Bell, J. R.; Jones, J. H. J. Chem. Soc., Perkin Trans. I 1974, 2336; (c) Also see references in ref. 10.

9. (a) Lipshutz, B. H.; Morey, M. C. J. Org. Chem. 1983, 48, 3745; (b) Martin, P. K.; Matthews, H. R.; Rapoport, H.; Thyagarajan, G. J. Org. Chem. 1968, 33, 3758; (c) Fran, 1.; Zeller, M. Synth. Commun. 1990, 20, 2519; (d) Al-Shaar, A. H.; Gilmour, D. W.; Lythgoe, D. J.; McClenaghan, I.; Ramsden, C.A. J. Chem. Soc., Chem. Commun. 1989, 551; (e) Brown, T.; Shaw, G. Durant, G. J. J. Chem. Soc. Perkin Trans. I 1983, 809; (f) Antonini, I.; Cristalli, G.; Franchetti, P.; Grifantini, M.; Martelli, S. Synthesis 1983, 47.

10. Matthews, H. R.; Rapopor, H. J. Am. Chem. Soc. 1973, 95, 2297.

11. (a) Amino, Y.; Eto, H.; Eguchi, C. Chem. Pharm. Bull. 1989, 37, 1481; (b) Campbell, J. B. J. Chem. Soc. Perkin Trans I 1983, 1213; (c) Duke, C. C.; Eichholzer, J. V.; MacLeod, J. K. Aust. J. Chem. 1981, 34, 1739.

12. Yasuda, N.; Nakamura, A.; Tsuboi, M. J. Heterocyclic Chem. 1987, 24, 303.

13. Chan, E.; Putt, S. R.; Showalter, H. D. H.; Baker, D. C. J. Org. Chem. 1982, 47, 3457.

14. Graden D. W.; Cotter, M. L.; Levine, S. D. J. Org. Chem. 1985, 50, 5878.

15. Colombo, R.; Colombo, F.; Derome, A. E.; Jones, J. H.; Rathbone, D. L.; Thomas, D. W. J. Chem. Soc. Perkin Trans I 1985, 1811.

16. Xu, X.; Westler, W. M.; Markley, J. L. J. Magn. Reson. 1984, 59, 524.

17. Banoub, J. H.; Becchi, M.; Descotes, G.; Fraisse, D.; Rumble, R. W.; Mackenzie, G. J. Carbohydr. Chem. 1992, 11, 471.

18. Leone-Bay, A. U. S. Patent US 4,711,962, 1987; Chem. Abstr. 1988, 109, 129017j.

19. Kasina, S.; Nematollahi, J. Synthesis 1975, 162.

20. Takahashi, K.; Mitsuhashi, K. Bull. Chem. Soc. Jpn. 1980, 53, 557.

21. Subrayan, R. P., Ph.D Thesis, The University of Michigan, Ann Arbor, 1993.

22. O'Connel, J. F.; Parquette, J.; Yelle, W. E.; Wang, W.; Rapoport, H. Synthesis 1988, 767.

23. Kim, C. S.; Lee, K. J.; Kim, H. S.; Chae, Y. B. J. Heterocyclic Chem. 1983, 20, 1417.

24. March, J. Advanced Organic Chemistry John Wiley \& Sons, Inc., New York, 3rd Ed., 1985, pp. 792. 
25. (a) Japan Kokai Tokkyo Koho 80 94959, 1980; Chem. Abstr. 1981, 94, 17113c; (b) Segawa, H.; Takagi, T.; Aida, K. Japan Kokai 51-11765 1976; Chem. Abstr. 1976, 84, 180224s.

26. Ratios of 5:1 - 6:1 (5b \& 5c) have been obtained in the large scale methylation of 5a; Bouck, K. J.; Rasmussen, P.G., unpublished results from this laboratory.

27. The crystal dimensions were $0.05 \times 0.05 \times 0.6 \mathrm{~mm}$. The crystal has a body-centered tetragonal cell with the dimensions $\mathrm{a}=\mathrm{b}=32 \AA, c=4 \AA$ with 16 molecules in the unit cell. Apparently, the crystal growth is along the $c$ axis like stacking cards. Disorder has prevented the complete determination of crystal structure.

28. Monocyanoimidazoles have been synthesized by the cyclization of $\mathrm{N}$-substituted derivatives of diaminomaleonitrile (Booth, B. L.; Freoas, A. P.; Proença, M. F. J. R. P. J. Chem. Res(S) 1993, 260; J. Chem. Res.(M) 1993, 1640). 4(5)-Cyanoimidazoles have been synthesized in good yields by the reaction of ammonium hydroxide on 4(5)-trifluoromethylimidazoles (Matthews, D. P.; Whitten, J. P.; McCarthy J. R. J. Org. Chem. 1986, 51, 3228). Monocyanoimidazoles have also been synthesized by photolysis of diaminomaleonitrile (Koch, T. H.; Rodehorst, R. M. J. Am. Chem. Soc. 1974, 96, 6707) and aminomethylenemalononitrile (Ferris, J. P.; Trimmer, R. W. J. Org. Chem. 1976, 41, 19). On the other hand, syntheses of 2-cyanoimidazoles have been reported by the cyanation of imidazoles using cyanogen bromide (Whitten, J. P.; McCarthy, J, R.; Matthews, D. P. Synthesis 1988, 470) or cyanogen chloride (McCarthy, J. R.; Matthews, D. P.; Whitten, J. P. Tetrahedron Lett. 1985, 26, 6273) or by phenyl cyanate or tosyl cyanide (Dudfield, P. J.; Ekwuru, C. T.; Hamilton, K.; Osboum, C. E.; Simpson, D. J. Synlett 1990, 277).

(Received in USA 15 September 1993; accepted 13 December 1993) 